\title{
Documentation of fungal endophytes of black pepper (Piper nigrum L.) and their seed transmission studies
}

\author{
K Sreeja*, M Anandaraj \& R Suseela Bhai \\ ICAR-Indian Institute of Spices Research, Kozhikode-673 012, Kerala. \\ *E-mail: sreejajyothi@gmail.com
}

Received 23 July 2019; Revised 01 November 2019; Accepted 04 November 2019

\begin{abstract}
The present study envisaged to document the endophytic fungal association with black pepper through a series of in vitro and in planta investigations. Black pepper was found to harbour endophytic fungal flora belonging to the genera Alternaria, Acremonium, Aspergillus, Cladosporium, Chaetomium, Curvularia, Colletotrichum, Fusarium, Humicola, Paecilomyces, Rhizoctonia, Phoma and non-sporulating forms. Further, it was found that the endocarp of black pepper seed is free from culturable endophytic fungi. This was evident from the absence of culturable fungi in in vitro grown black pepper seedlings. The growth of fungi from the seedlings grown under green house conditions reveal that the fungal endophytes establish from fungal propagules falling on the (test) plants that may enter the plant tissues as back ground inoculum and grow as endophyte. This was also supported by the study that the type of endophytic fungi that harbour black pepper plants varied with geographical locations from where the samples were collected.
\end{abstract}

Keywords: black pepper, endophytic fungi, in vitro germination, seed transmission

\section{Introduction}

Black pepper (Piper nigrum L.), is a perennial climbing vine belonging to the family Piperaceae of the order Piperales (Ravindran 2000). It is considered to have originated in the Western Ghats of India and, apart from its country of origin, now it is grown in Brazil, Cambodia, China, Guatemala, Indonesia, Malaysia, Mexico, Sri Lanka, Thailand, and Vietnam. In India, Kerala and Karnataka are the main states that grow black pepper; However, Tamil Nadu and a few other states also contribute a small share to the total production. The production system for black pepper in India is totally sustainable because black pepper is commonly cultivated as an intercrop in homesteads, while as a main crop or monocrop in plantations. Though the crop is susceptible to many diseases, there are plantations or homesteads where black pepper remained healthy and yield profusely. This can be attributed to lack of pathogen inoculum and can also be due to the presence of potential endophytes inside the tissues that protect the crop from getting infection through external inoculum. The endophytes include both culturable and non-culturable microbes including bacteria, fungi or even viruses. 
According to recently accepted definition, endophytes are those highly diverse fungi that colonize internal tissues of plants either partly or complete their life without causing any negative symptoms of disease (Verma et al. 2017). Endophytic fungal associations have been found in almost all classes of vascular plants and grasses (Jalgaonwala et al. 2011). Many host plants and especially medicinal plants could be a valuable repository for fungal endophytes yielding novel metabolites of agricultural and medicinal importance (Kusari et al. 2014 \& Nisa et al. 2015). Endophytic fungi enter the plants either horizontally (Arnold et al. 2007 \& Sieber et al. 2007) or vertically (Saikkonen et al. 2016). Substantial work on endophytic fungi has been reported from various host plants including medicinal plants. In black pepper, fungal endophytes remain largely unexplored. Not enough information is available on internal mycobiota, method of transmission, and biological role in black pepper. The available data on black pepper fungal endophytes were from the studies by Mathew et al. (2011) to control P. capsici. A bioprospecting study by Chithra et al. (2014) identified the role of endophytic fungi in producing a natural alkaloid piperine. The objectives of our study were to isolate and document the endophytic fungal association in different varieties of black pepper, their morphological identification, fungal composition in different tissues and to understand the nature of fungal association with black pepper.

\section{Materials and methods}

\section{Isolation of endophytic fungi}

The stem, leaves and roots collected randomly from healthy black pepper vines trained on living standards were used for isolation of endophytic fungi. Twenty five samples of stem, leaves and roots were collected from seven black pepper gardens of Kerala and Karnataka including the varieties Sreekara, Subhakara, Panniyur 1 and Panniyur 3. The collected samples were kept in plastic bags, labeled and transported to the laboratory and processed for the isolation of endophytic fungi. The experiment was conducted at the Biocontrol Laboratory of ICARIndian Institute of Spices Research, Kozhikode, Kerala, India. Pure cultures of fungi were maintained in PDA slants (Sreeja et al. 2016) kept in refrigerator at $4^{\circ} \mathrm{C}$. The viability of the isolates was maintained by periodic transfer to fresh medium at six months interval.

\section{Estimation of isolation rate and colonization rate}

Isolation rate (IR), the measure of fungal richness of a sampled tissue was calculated by taking the number of isolates obtained from a sample divided by the total number of samples plated, and expressed in fractions not in percentage (Wang \& Guo 2007). Colonization rate (CR) was expressed in percentage and was calculated as number of samples yielding $\geq 1$ isolate $x 100$ / the total number of samples tested.

\section{Morphological identification of endophytic fungal} isolates

One hundred twenty five endophytic fungi isolated from different samples of black pepper were identified based on colony morphology, growth rate, mycelial texture, colour and production of pigments and microscopic examination of fungal structures (size and shape of hyphae and conidial characters) adopting slide culture technique. For slide culture, mycelial bits were inoculated to a sterile microscopic slide coated with a thin layer of PDA and incubated till thin mycelial mats were formed. The slides were stained with lacto phenol cotton blue (HIMEDIA) and covered with a sterile cover glass. The stained slides were observed under the microscope for fungal structures. The isolates that failed to sporulate on continuous culturing on different media under varying incubation conditions were recorded as non sporulating type.

Induction of sporulation in non sporulating endophytic fungi

The non sporulating fungal cultures were sub cultured on different media viz., Potato Dextrose Agar (PDA), Rose Bengal Agar 
(RBA), Corn Meal Agar (CMA) and Water Agar (WA). The inoculated plates were incubated at different incubation conditions like under dark, under UV and white fluorescent light (for a light regime of 12:12 h light: dark). In addition to this, modified protocol of Guo et al. (1998) was also tried to induce sporulation by inoculating fungal cultures on black pepper leaf segments placed on Petri plates and incubated at $20^{\circ} \mathrm{C}$ under both dark and $12: 12 \mathrm{~h}$ light : dark cycles. The inoculated cultures were observed periodically for sporulation, and once sporulated, the fungi were identified based on morphological characters by comparing the standard monographs and literature.

\section{Screening of black pepper seeds for endophytic fungal association}

Black pepper seeds (both matured un-ripe seed and ripened seeds) were collected from varieties viz., Sreekara and Panniyur1 from the field grown black pepper vines at ICAR-IISR, Kozhikode. The experiment was set up in two sets. In the first set, whole seeds (matured unripe and ripened seeds) were surface sterilized by dipping in sodium hypochlorite $3-5 \%$ available chlorine) for $5 \mathrm{~min}$, then with $70 \%$ ethanol for $2 \mathrm{~min}$ and rinsed in sterile distilled water thrice. The sterilized seeds were kept for drying on sterile filter paper. In the second set, the pericarp of the seeds was removed physically and the endocarp of the seeds was surface sterilized as above. After surface drying, the seeds were cut in to half and inoculated on to malt extract agar medium. The plates were incubated at room temperature and periodically observed for fungal growth.

Screening of black pepper seedlings for endophytic fungal association

Following experiments were conducted to study the association of endophytic fungi in black pepper seedlings grown in vivo and in vitro.

Screening in vivo grown black pepper seedlings for endophytic fungal association

Ripened seeds of variety Sreekara collected randomly from vines grown at ICAR-IISR, Kozhikode were used for this study with the following treatments: T1- plastic trays filled with sterile potting mixture consisting of soil: sand: cow dung in the ratio of 1:1:1 (sterilized by autoclaving at $121^{\circ} \mathrm{C}$ for $1 \mathrm{~h}$ for three times at an interval of $48 \mathrm{~h}$ ) and T2- same potting mixture without sterilization. Both the treatments were seeded with one hundred seeds and kept for germination. There were six replications for each treatment. The seeded trays were kept in green house with an average temperature of $26-30^{\circ} \mathrm{C}$ and maintained by regular watering with sterile water. After four months of growth, five healthy plants were selected from each tray, washed in sterile water and kept for surface drying. The stem, root and leaf tissues (five segment/tissue/seedling) of the seedlings were used for endophytic fungal isolation. The inoculated plates were kept for incubation at room temperature under dark. The plates were periodically observed for fungal growth and recorded the observations.

Screening of in vitro grown black pepper seedlings for endophytic fungal association

The ripened black pepper seeds of the variety Sreekara (collected from ICAR-IISR, Kozhikode) were used for the study. The seeds were soaked overnight in water and the outer pericarp was removed by gentle rubbing. The seeds (without outer pericarp) were washed several times in sterile water before surface sterilization in order to remove the outer coat completely. The surface sterilized seeds (five seeds/ tubes were kept with 25 replications for each treatment) were seeded for in vitro germination in test tubes with the following treatments; $\left(\mathrm{T}_{1}\right)=$ sterile sand with $30 \%$ moisture, $\left(\mathrm{T}_{2}\right)=$ sterile vermiculite with $30 \%$ moisture, $\left(\mathrm{T}_{3}\right)=$ water agar $(1 \%),\left(\mathrm{T}_{4}\right)=$ half strength MS medium (Murashige \& Skoog 1962) and $\left(\mathrm{T}_{5}\right)=$ unsterilized sand ( $30 \%$ moisture). The tubes were kept at $24^{\circ} \mathrm{C}$ under 12 hours of alternate dark and light cycles until germination of seeds. Hoagland's solution was applied to plants for better growth. Observations were recorded on germination and establishment 
of seedlings on each substrate. The percentage germination was estimated using the formula:

(Number of seedlings germinated / Total number of seeds kept for germination) $\times 100$

In order to check the seedlings for endophytic fungal association, healthy contamination free seedlings (25 numbers) were carefully removed from each treatment used for in vitro germination; $\mathrm{T}_{1}$ (sterile sand), $\mathrm{T}_{3}$ (water agar), and $\mathrm{T}_{5}$ (unsterile sand). No plant was used from $\mathrm{T}_{3}$ and $\mathrm{T}_{4}$ as no growth was observed. The seedlings were washed in sterile distilled water and kept for surface drying in sterile filter paper. The stem, root and leaf tissues were cut with a sterile scalpel, surface-sterilized as described earlier and kept for endophytic fungal isolation and the plates were observed regularly and recorded the fungal growth.

\section{Results and discussion}

Isolation of endophytic fungi

The time taken for growth initiation of endophytic fungi from black pepper (the earliest day of fungal growth observed during incubation) varied with fungi and ranged from 9-24 days. Out of 525 tissue samples of black pepper examined (Table 1) for endophytic fungal growth, 95 samples $(18.1 \%)$ showed fungal growth. The overall isolation rate of endophytic fungi from four black pepper varieties was found to be 0.24 . The stem tissues of Sreekara collected from ICAR-IISR Experimental Farm, Peruvannamuzhi showed the highest isolation rate followed by root and stem tissues of Panniyur 1 collected from Mudigere, Karnataka and Chelavoor, Kozhikode, respectively (Fig. 1 ). The isolation rates of leaf tissues among the samples were found to be less than 0.3

From 95 tissues of black pepper with fungal growth, a total of 125 fungi were isolated in pure culture ( 46 from stem, 44 from root and the remaining 35 from leaves). The overall endophytic fungal colonization rate in black pepper was found to be $18.0 \%$. The stem sample collected from variety Sreekara, (Peruvannamuzhi, Kozhikode) showed highest CR followed by stem sample of Panniyur1, collected from Chelavoor, Kozhikode. The CR of stem tissues ranged from $10-40 \%$ and that of leaf tissues ranged from 10-20\% (Fig. 2 ). These fungi were already reported as endophytes of other plants and also support the fact that most of the endophytes isolated belong to Ascomycetes, their anamorphs and Basidiomycetes (Suryanarayanan et al. 2011).

\section{Identification of endophytic fungi}

Out of 125 endophytic fungi isolated from stem, root and leaves of black pepper, the predominant colonizers were sporulating types $(76 \%)$. The morphological identification of sporulating fungi was done by microscopy up to genus level. The identified endophytic fungi of black pepper include 12 genera, namely Alternaria, Acremonium, Aspergillus, Cladosporium, Chaetomium, Curvularia, Colletotrichum, Fusarium, Humicola, Paecilomyces, Rhizoctonia and Phoma (Table 2).

Table 1. Overall isolation pattern of endophytic fungi from black pepper tissues

\begin{tabular}{llllll}
\hline Tissue & $\begin{array}{l}\text { No. of } \\
\text { samples }\end{array}$ & $\begin{array}{l}\text { No. of samples } \\
\text { yielding isolates }\end{array}$ & $\begin{array}{l}\text { No. isolates } \\
\text { recovered }\end{array}$ & $\begin{array}{l}\text { Colonization } \\
\text { rate (CR) \% }\end{array}$ & $\begin{array}{l}\text { Isolation rate } \\
\text { (IR) }\end{array}$ \\
\hline Stem & 175 & 36 & 46 & 20.6 & 0.26 \\
Root & 175 & 30 & 34 & 17.1 & 0.19 \\
Leaf & 175 & 29 & 45 & 16.6 & 0.25 \\
Total & 525 & 95 & 125 & 18.1 & 0.24 \\
\hline
\end{tabular}


Table 2. Taxonomic identity of endophytic fungal isolates from different parts and varieties of black pepper

\begin{tabular}{|c|c|c|c|c|}
\hline SI. No. & Place of collection & Variety & $\begin{array}{l}\text { Tissue } \\
\text { type }\end{array}$ & Identity \\
\hline \multirow[t]{6}{*}{1} & \multirow[t]{6}{*}{$\begin{array}{l}\text { Chelavoor, } \\
\text { Kozhikode }\end{array}$} & \multirow[t]{3}{*}{ Sreekara } & Stem & $\begin{array}{l}\text { Phoma sp., Sterile morphotype, F. Oxysporum, C. } \\
\text { gloeosporioides, Fusarium sp. }\end{array}$ \\
\hline & & & Leaf & $\begin{array}{l}\text { C. gloeosporioides, Sterile morphotype, Chaetomium } \\
\text { sp. Cladosporium sp. Fusarium sp. }\end{array}$ \\
\hline & & & Root & $\begin{array}{l}\text { Sterile morphotype F. oxysporum, Phoma sp., F. } \\
\text { oxysporum, Fusarium sp. Humicola sp., A. niger }\end{array}$ \\
\hline & & \multirow[t]{3}{*}{ Panniyur 1} & Stem & $\begin{array}{l}\text { F. oxysporum, Sterile morphotype, A. niger, Sterile } \\
\text { morphotype, F. oxysporum, C. gloeosporioides, } \\
\text { Fusarium sp. }\end{array}$ \\
\hline & & & Leaf & $\begin{array}{l}\text { Chaetomium sp., Sterile morphotype, F. oxysporum, } \\
\text { Curvularia sp., A. fumigates }\end{array}$ \\
\hline & & & Root & $\begin{array}{l}\text { Sterile morphotype, Humicola sp., Fusarium sp., } \\
\text { Phoma sp. }\end{array}$ \\
\hline \multirow[t]{3}{*}{2} & \multirow[t]{3}{*}{$\begin{array}{l}\text { Sakaleshpur, } \\
\text { Hassan }\end{array}$} & \multirow[t]{3}{*}{ Panniyur 1} & Stem & $\begin{array}{l}\text { Colletotrichum sp., C. gloeosporioides, F. oxysporum, } \\
\text { Sterile morphotype, C. gloeosporioides, Fusarium sp. }\end{array}$ \\
\hline & & & Root & $\begin{array}{l}\text { Sterile morphotype, F. oxysporum, Cladosporium } \\
\text { sp., Fusarium sp. }\end{array}$ \\
\hline & & & Leaf & $\begin{array}{l}\text { C. gloeosporioides, Curvularia sp., Fusarium sp., } \\
\text { Colletotrichum sp., Chaetomium sp. }\end{array}$ \\
\hline \multirow[t]{3}{*}{3} & \multirow[t]{3}{*}{$\begin{array}{l}\text { Mudigere, } \\
\text { Chikkamagaluru }\end{array}$} & \multirow[t]{3}{*}{ Panniyur 1} & Stem & $\begin{array}{l}\text { Sterile morphotype, Fusarium sp., F. oxysporum, C. } \\
\text { gloeosporioides }\end{array}$ \\
\hline & & & Root & $\begin{array}{l}\text { C. gloeosporioides, Sterile morphotype, } \\
\text { F. oxysporum, Phoma sp., Fusarium sp., A. fumigates }\end{array}$ \\
\hline & & & Leaf & $\begin{array}{l}\text { Paecilomyces sp., F. oxysporum, } \\
\text { C. gloeosporioides, Cladosporium sp., A. alternata }\end{array}$ \\
\hline \multirow[t]{3}{*}{4} & \multirow[t]{3}{*}{$\begin{array}{l}\text { Chelavoor, } \\
\text { Kozhikode }\end{array}$} & \multirow[t]{3}{*}{ Subhakara } & Stem & $\begin{array}{l}\text { C. gloeosporioides, F. oxysporum, } \\
\text { Sterile morphotype, C. cladosporioides }\end{array}$ \\
\hline & & & Root & $\begin{array}{l}\text { F. oxysporum, Sterile morphotype, } \\
\text { A. fumigates, Rhizoctonia sp., Fusarium sp., } \\
\text { Humicola sp. }\end{array}$ \\
\hline & & & Leaf & $\begin{array}{l}\text { Sterile morphotype, F. oxysporum, } \\
\text { C. gloeosporioides, A. niger }\end{array}$ \\
\hline \multirow[t]{3}{*}{5} & \multirow[t]{3}{*}{$\begin{array}{l}\text { Peruvannamuzhi, } \\
\text { Kozhikode }\end{array}$} & \multirow[t]{3}{*}{ Panniyur 3} & Stem & $\begin{array}{l}\text { Acremonium sp., Phoma sp., F. oxysporum, } \\
\text { gloeosporioides, A. alternata }\end{array}$ \\
\hline & & & Root & $\begin{array}{l}\text { Sterile morphotype, Rhizoctonia sp., } \\
\text { Fusarium sp., C. gloeosporioides, F. oxysporum, }\end{array}$ \\
\hline & & & Leaf & $\begin{array}{l}\text { Alternaria sp., C. gloeosporioides, } \\
\text { Paecilomyces sp., Sterile morphotype }\end{array}$ \\
\hline \multirow[t]{3}{*}{6} & \multirow[t]{3}{*}{$\begin{array}{l}\text { Peruvannamuzhi, } \\
\text { Kozhikode }\end{array}$} & \multirow[t]{3}{*}{ Sreekara } & Stem & $\begin{array}{l}\text { C. gloeosporioides, Fusarium sp., } \\
\text { Sterile morphotype, Alternaria sp., F. oxysporum, } \\
\text { Colletotrichum sp., A. fumigates }\end{array}$ \\
\hline & & & Root & $\begin{array}{l}\text { F. oxysporum, Phoma sp., Fusarium sp., Rhizoctonia } \\
\text { sp., Sterile morphotype, Cladosporium sp. }\end{array}$ \\
\hline & & & Leaf & $\begin{array}{l}\text { Colletotrichum sp., Fusarium sp., Acremonium sp., } \\
\text { Sterile morphotype, F. oxysporum }\end{array}$ \\
\hline
\end{tabular}




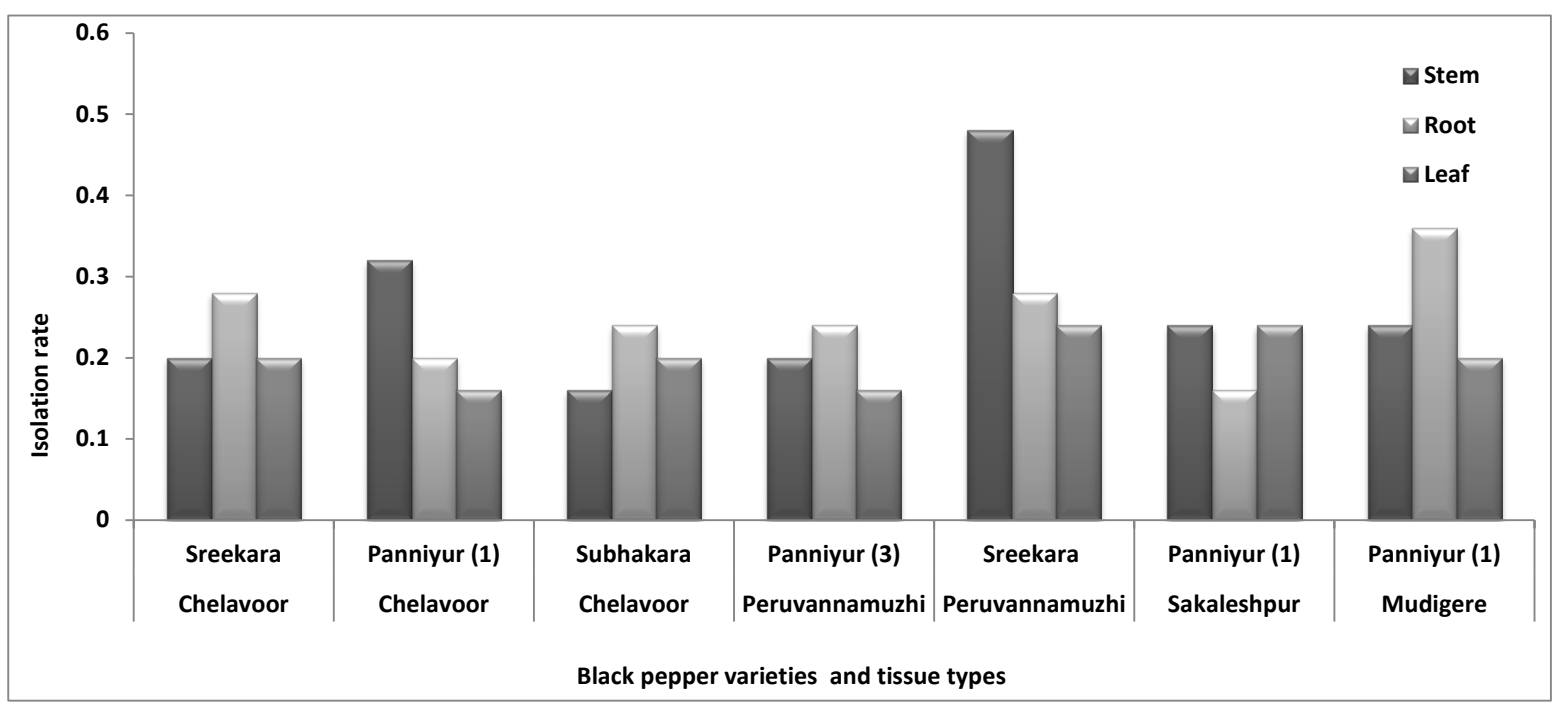

Fig. 1. Isolation rates of endophytic fungi in various tissues of black pepper

Induction of sporulation in non sporulating endophytic fungi

Out of the 125 endophytic fungal isolates 30 isolates $(24 \%)$ were initially found to be non sporulating types. The non sporulating endophytic fungi were exposed to various sporulation inducing methods. Among the 30 non sporulating isolates, only five isolates sporulated in PDA and CMA incubated in dark for 20-30 days. These isolates were morphologically identified as Colletotrichum sp. No sporulation was observed in remaining 25 isolates exposed to similar conditions.
Screening of black pepper seeds for endophytic fungal association

In this study, 1600 black pepper seeds collected from both Sreekara and Panniyur 1 were screened for endophytic association. Seeds inoculated as whole seeds (with pericarp) yielded fungal isolates after 15 -20 days of incubation. No fungal growth was observed from endocarp segments. The isolation rates from the whole seeds were found to be $0.06 \%$ (Table 3). The matured unripe seeds showed higher isolation rate compared to ripened seeds and highest isolation rate was observed

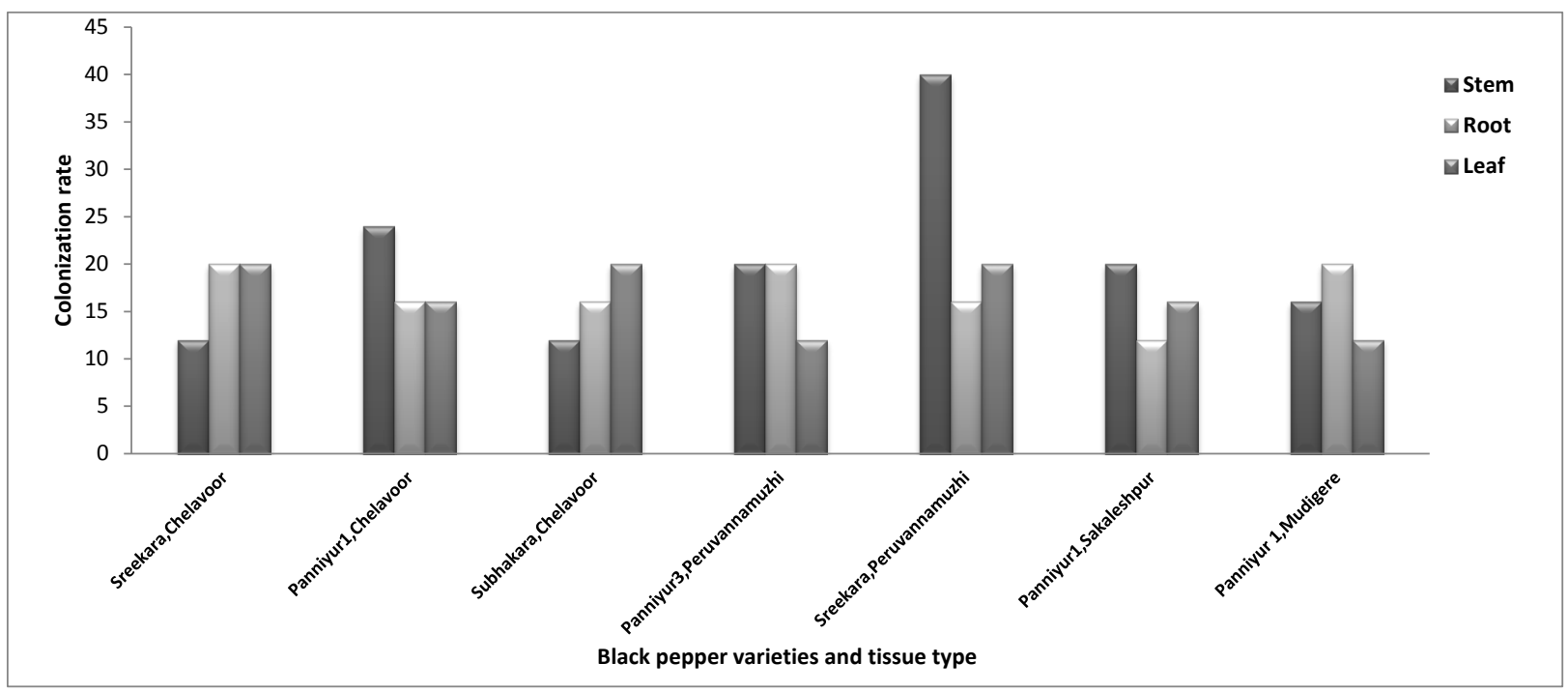

Fig. 2. Colonization rate (\%) of endophytic fungi from various tissues of black pepper 
Table 3. Screening of black pepper seeds for endophytic fungi

\begin{tabular}{|c|c|c|c|c|c|c|c|c|c|}
\hline \multirow[t]{3}{*}{ Parameter } & \multicolumn{4}{|c|}{ Sreekara } & \multicolumn{4}{|c|}{ Panniyur 1} & \multirow[t]{3}{*}{ Total } \\
\hline & \multicolumn{2}{|c|}{$\begin{array}{l}\text { Mature un } \\
\text { ripened seeds }\end{array}$} & \multicolumn{2}{|c|}{$\begin{array}{l}\text { Ripened } \\
\text { seeds }\end{array}$} & \multicolumn{2}{|c|}{$\begin{array}{l}\text { Mature un } \\
\text { ripened seeds }\end{array}$} & \multicolumn{2}{|c|}{$\begin{array}{l}\text { Ripened } \\
\text { seeds }\end{array}$} & \\
\hline & $\mathrm{W}$ & E & $\mathrm{W}$ & E & $\mathrm{W}$ & $\mathrm{E}$ & $\mathrm{W}$ & E & \\
\hline No. of samples plated & 200 & 200 & 200 & 200 & 200 & 200 & 200 & 200 & 1600 \\
\hline $\begin{array}{l}\text { No. of samples yielding } \\
\text { isolates }\end{array}$ & 12 & - & 10 & - & 14 & - & 8 & - & 44 \\
\hline No. of isolates obtained & 14 & - & 11 & - & 16 & - & 12 & - & 53 \\
\hline Colonization rate $\%(\mathrm{CR})$ & 6 & - & 5 & - & 7 & - & 4 & - & 5 \\
\hline Isolation rate (IR) & 0.07 & - & 0.06 & - & 0.08 & - & 0.06 & - & 0.06 \\
\hline
\end{tabular}

W=whole seed; $\mathrm{E}=$ endocarp

in young seeds of Panniyur1 compared to Sreekara. The average colonization rate was found to be $5 \%$. Out of the 53 isolates obtained, 50 were identified as Colletotrichum sp. and the remaining three isolates were non sporulating types.

Screening of in vivo grown black pepper seedlings for endophytic fungal association

Fungal growth was obtained from seedlings grown on both sterile and non-sterile substrates (Table 4). Out of the 450 tissues (root, stem and leaf) sampled from seedlings grown in non-sterile potting mixture, 68 tissues showed fungal growth with an isolation rate of $0.18 \%$. Among the 68 isolates, 19 were obtained from stem, 26 from root and 23 from leaf. The average colonization rate was found to be $15 \%$. In case of seedlings grown in sterile potting mixtures, 40 segments out of 450 samples showed fungal growths with an average isolation rate of $0.11 \%$. No significant difference was observed between the leaf and root tissues in the isolation rate from seedlings grown on sterile sand whereas, less isolation rate was observed in stem tissues. From the 40 segments a total of 51 isolates were recovered, which included 14 from stem, 17 from root and 20 from leaf. Compared to the seedlings grown on sterile potting mixture, higher isolation rate and colonization rates (\%) were observed in those grown on non-sterile potting mixture.
Screening of in vitro grown black pepper seedlings for endophytic fungal association

In vitro germination of black pepper seeds (endocarp) was done with four different substrates namely sterile sand (30\% moisture), water agar $(1 \%)$, vermiculite and half MS medium. The tissues (stem, root and leaf) of seedlings grown on water agar as well as sterilized sand were found to be free from endophytic fungi (Fig. 3). Tissues did not show any fungal growth even after prolonged incubation. Whereas tissues of seedlings in the control tubes (tubes with nonsterile sand), showed fungal growth in all the three tissues incubated even though the isolation rate was low. The in vitro germination of black pepper seeds and production of sterile seedlings helps in the seed transmission studies. Such studies were also reported in cocoa by Bailey et al. (2008).

In the present study, endophytic fungi were isolated from roots, stem, leaves and fruits of black pepper varieties viz., Sreekara, Subhakara, Panniyur 1 and Panniyur 3 from gardens of Kerala and Karnataka states of India. The findings were anticipated as it was reported from most of the plants studied (Khiralla et al. 2017) and there were previous reports of endophytic isolations from stem, root and leaves of black pepper (Aravind et al. 2010; Mathew et al. 2011; Chithra et al. 2014). Among 
Table 4. Screening of in vivo grown black pepper seedlings for endophytic fungi

\begin{tabular}{|c|c|c|c|c|c|c|c|c|}
\hline \multirow[t]{2}{*}{ Parameter } & \multicolumn{4}{|c|}{$\begin{array}{l}\text { Seedlings from unsterilized } \\
\text { potting mixture }\end{array}$} & \multicolumn{4}{|c|}{$\begin{array}{l}\text { Seedlings from sterilized potting } \\
\text { mixture }\end{array}$} \\
\hline & S & $\mathrm{R}$ & $\mathrm{L}$ & Total & $S$ & $\mathrm{R}$ & $\mathrm{L}$ & Total \\
\hline No. of samples plated & 150 & 150 & 150 & 450 & 150 & 150 & 150 & 450 \\
\hline No. of samples yielding isolates & 19 & 26 & 23 & 68 & 12 & 13 & 15 & 40 \\
\hline No. of isolates recovered & 23 & 31 & 28 & 82 & 14 & 17 & 20 & 51 \\
\hline Colonization rate \% (CR) & 13 & 17 & 15 & 15 & 8 & 9 & 10 & 27 \\
\hline Isolation rate (IR) & 0.15 & 0.2 & 0.18 & 0.18 & 0.09 & 0.13 & 0.13 & 0.11 \\
\hline
\end{tabular}

$\mathrm{S}=$ stem; R=root and L=leaf. Isolation rate IR; presented as fraction

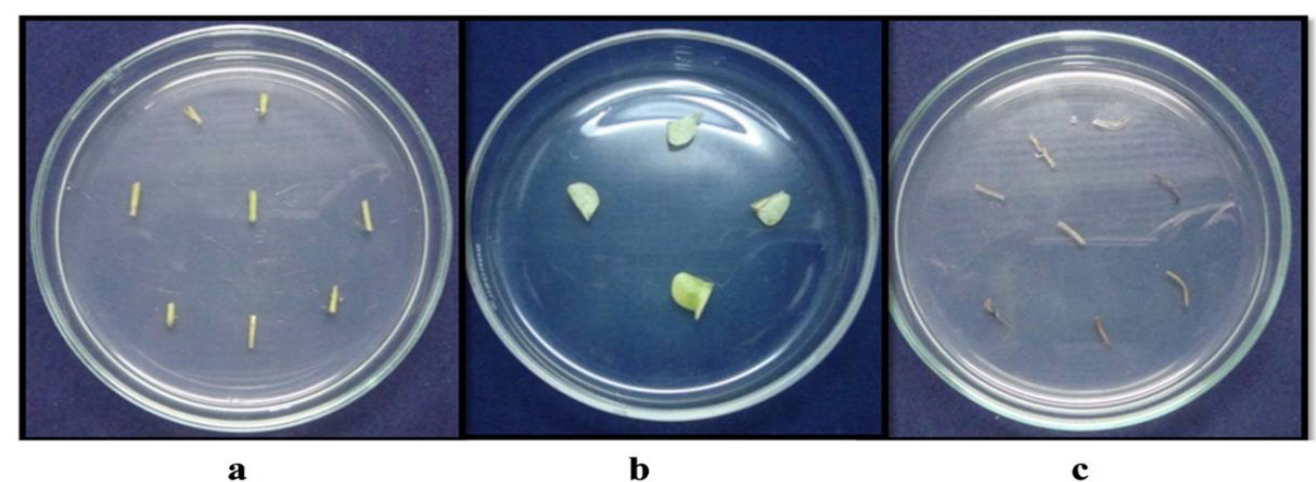

Fig. 3. Tissues of in vitro grown black pepper seedlings in MEA medium. a) Stem b) Leaf c) Root

the endophytic genera isolated, non-sporulating sterile morphotypes $(31.3 \%)$ are present throughout apart from species of Colletotrichum (22.9\%) and Fusarium (28.3\%), that were present in all the plant parts irrespective of varieties and geographic locations. All the samples including stem, leaf and root tissues of all the varieties tested as well as from all the locations showed the growth of these fungi. Species of Acremonium, Cladosporium etc were observed as leaf residents, whereas Humicola, Rhizoctonia and Phoma species were found mostly as root colonizers. Alternaria spp. was observed both in the root and leaf tissues, while Aspergillus spp. was observed occasionally in leaf and stem tissues. Raviraja (2005) reported that the fungi viz., Curvularia clavata, C. lunata, C. pallescens and F. oxysporum were dominantly isolated from bark, stem and leaf segments of five medicinal plants species growing in the Western Ghats of India. In vitro grown seedlings were found to be free from fungal endophytes based on culture based techniques. Thus the results of isolation of endophytic fungi from black pepper seedlings grown under in vitro and in vivo conditions suggest that under strict aseptic conditions black pepper plants are free from endophytic fungi, whereas the endophytes found associated with black pepper are natural invaders or extruders.

\section{Acknowledgements}

The authors are grateful to ICAR for funding. Facilities and support obtained from Head, Division of Crop Protection, ICAR-IISR, Kozhikode and members of PhytoFuRa are thankfully acknowledged. 


\section{References}

Aravind R, Eapen S J, Kumar A, Dinu A \& Ramana K V 2010 Screening of endophytic bacteria and evaluation of selected isolates for suppression of burrowing nematode (Radopholus similis Thorne) using three varieties of black pepper (Piper nigrum L.). Crop Prot. 29: 318-324.

Arnold A E 2007 Understanding the diversity of foliar endophytic fungi: progress, challenges, and frontiers. Fungal Biol. Rev. 21: 51-66.

Bailey B A, Bae H, Strem M D, Crozier J, Thomas S E, Samuels G J \& Holmes K A 2008 Antibiosis, mycoparasitism, and colonization success for endophytic Trichoderma isolates with biological control potential in Theobroma cacao. Biol. Control. 46: 24-35.

Chithra S, Jasim B, Sachidanandan P, Jyothis M \& Radhakrishnan E K 2014 Piperine production by endophytic fungus Colletotrichum gloeosporioides isolated from Piper nigrum. Phytomed. 21: 534-540.

Guo L D, Hyde K D \& Liew E C Y 1998 A method to promote sporulation in palm endophytic fungi. Fungal Divers. 1: 109-113.

Hata K \& Futai K 1995 Endophytic fungi associated with healthy pine needles and needles infested by the pine needle gall midge, Thecodiplosis japonensis. Can. J. Bot. 73: 384-390.

Jalgaonwala R E, Mohite B V \& Mahajan R T 2011 A review: natural products from plant associated endophytic fungi. Int. J. Microbiol. Biotechnol. 1: 21-32.

Jia M, Chen L, Xin H L, Zheng C J, Rahman K, Han T \& Qin L P 2016 A friendly relationship between endophytic fungi and medicinal plants: a systematic review. Front. Microbiol. 7.

Khiralla A, Mohamed I, Thomas J, Mignard B, Spina R, Yagi S \& Laurain-Mattar D 2015 A pilot study of antioxidant potential of endophytic fungi from some Sudanese medicinal plants. Asian Pac. J. Trop. Med. 8: 701-704.

Kusari S, Singh S \& Jayabaskaran C 2014 Biotechnological potential of plantassociated endophytic fungi: hope versus hype. Trends Biotechnol. 32: 297-303.

Mathew S K, Mary C G, Gopal K S \& Girija D 2011 Antagonistic activity of endophytic Trichoderma against Phytophthora rot of black pepper (Piper nigrum L.). Biol. Control. 25: $48-50$.

Murashige T \& Skoog F 1962 A revised medium for rapid growth and bio assays with tobacco tissue cultures. Physiol. Plant. 15: 473-497.

Nalini M S, Sunayana N \& Prakash H S 2014 Endophytic fungal diversity in medicinal plants of Western Ghats, India. Int. J. Biodivers. Conserv. pp.9.

Nisa H, Kamili A N, Nawchoo I A, Shafi S, Shameem N \& Bandh S A 2015 Fungal endophytes as prolific source of phytochemicals and other bioactive natural products: a review. Microb. Pathog. 82: 50-59.

Ravindran P N 2000 Introduction in black pepper Piper nigrum L. In: Ravindran P N (Ed.), Black pepper monograph. Harwood Academic Publishers, pp.1-22.

Raviraja NS 2005 Fungal endophytes in five medicinal plant species from Kudremukh Range, Western Ghats of India. J. Basic Microbiol. 45: 230-235.

Saikkonen K, Young C A, Helander M \& Schardl C L 2016. Endophytic Epichloë species and their grass hosts: from evolution to applications. Plant Mol. Biol. 90: 665-675.

Sieber T N 2007 Endophytic fungi in forest trees: are they mutualists?. Fungal Biol. Rev. 21: 75-89.

Sreeja K, Anandaraj M \& Suseela Bhai R 2016 In vitro evaluation of fungal endophytes of black pepper against Phytophthora capsici and Radopholus similis. J. Spices Arom. Crops 25: 12-17.

Suryanarayanan T S, Murali T S, Thirunavukkarasu N, Rajulu M G, Venkatesan G \& Sukumar R 2011 Endophytic fungal communities in woody perennials of three tropical forest types of the Western Ghats, southern India. Biodivers. Conserv. 20: 913-928.

Verma S K, Gond S K, Mishra A, Sharma V K, Kumar J, Singh D K \& Kharwar R N 2017 Fungal Endophytes Representing Diverse Habitats and Their Role in Plant Protection. Developments in Fungal Biology and Applied Mycology. Springer, Singapore, pp.135-157.

Wang Y \& Guo L D 2007 A comparative study of endophytic fungi in needles, bark, and xylem of Pinus tabulaeformis. Bot. 85: 911-917. 